\title{
Post-flood status of the Endangered Ganges River Dolphin Platanista gangetica gangetica (Cetartiodactyla: Platanistidae) in the Koshi River, Nepal
}

\author{
Top Bahadur Khatri ${ }^{1}$, Deep Narayan Shah $^{2}$ \& Nilamber Mishra ${ }^{3}$ \\ ${ }^{1}$ Conservation and Sustainable Use of Wetlands in Nepal (CSUWN), Training Section Building, Second floor, Forestry Complex, \\ Babar Mahal, Kathmandu, Nepal \\ ${ }^{2}$ Conservation and Sustainable Use of Wetlands in Nepal (CSUWN), Koshi Tappu Wildlife Reserve, Paschim Kusaha, Sunsari, \\ Nepal. PO Box 20791, Sundhara, Kathmandu, Nepal \\ ${ }^{3}$ Department of National Parks and Wildlife Conservation, Koshi Tappu Wildlife Reserve, Paschim Kusaha, Sunsari, Nepal \\ Email: ${ }^{1}$ tbkhatri@wetlands.org.np, ${ }^{2}$ shahdeepnarayan@yahoo.com (corresponding author), ${ }^{3}$ nmishra@yahoo.com
}

Date of publication (online): 26 December 2010 Date of publication (print): 26 December 2010 ISSN $0974-7907$ (online) | $0974-7893$ (print)

\section{Editor: Gill Braulik}

\section{Manuscript details:}

Ms \# 02496

Received 29 June 2010

Final received 10 November 2010

Finally accepted 30 November 2010

Citation: Khatri, T.B., D.N. Shah \& N. Mishra (2010). Post-flood status of the Endangered Ganges River Dolphin Platanista gangetica gangetica (Cetartiodactyla: Platanistidae) in the Koshi River, Nepal. Journal of Threatened Taxa 2(13): 1365-1371

Copyright: (C) Top Bahadur Khatri, Deep Narayan Shah \& Nilamber Mishra 2010 Creative Commons Attribution 3.0 Unported License. JoTT allows unrestricted use of this article in any medium for non-profit purposes, reproduction and distribution by providing adequate credit to the authors and the source of publication.

Author Details: see end of this article.

Author Contribution: DNS conducted the field study and wrote up the paper. TBK and NM contributed by writing the paper as well as conducted field study.

Acknowledgements: We thank Dr. Gopa Sharma, Scientist 'B', Zoological Survey of India for constructive comments on an earlier version of the manuscript. Special thanks are due to Ram Devi T. Shah (Aquatic Ecologist, Hindu Kush Himalayan Benthological Society) for participation in the fieldwork during November, helpful comments in the draft version of the manuscript and assistance with the maps preparation.
Abstract: The breach of the eastern embankment of the Koshi Barrage at Paschim Kusaha Village of Sunsari District on 18 August 2008, created havoc for wildlife and their habitats, as well as people's livelihood and welfare. The Koshi River flowed through the breach for five months. Following the breach, a population assessment survey of the Endangered Ganges River Dolphin Platanista gangetica gangetica was made between March and November 2009 in the Koshi River main channel starting from Chatara to $2 \mathrm{~km}$ south of Koshi Barrage to ascertain their status. A direct count survey was conducted by two teams of researchers simultaneously searching for animals by boat from Chatara to the Koshi Barrage including the Triyuga River and on foot along the river banks downstream of Koshi Barrage and along the Mariya River. Standard protocols were followed to record the number of sighted dolphins. A total of 11 dolphins were recorded in the entire $49-\mathrm{km}$ river stretch with an encounter rate of 0.23 dolphins per $\mathrm{km}$. The current result showed an encouraging population of dolphins in the Koshi Tappu Wildlife Reserve and its buffer zone but the threats for conservation still remain challenging. Close monitoring of dolphins and their habitats involving local communities are required for long term conservation of the river dolphins in Nepal.

Keywords: Conservation, Ganges River Dolphin, human pressure, Koshi River, Nepal, status.

\section{INTRODUCTION}

River dolphins occurring in Asia and South America are amongst the world's most threatened mammal species (Kreb \& Budiono 2005) largely due to increasing human intervention into freshwater ecosystems. The freshwater dolphins inhabit some of the largest river systems in both Asia and South America. The Ganges River Dolphin Platanista gangetica gangetica, or Susu, is a freshwater dolphin distributed throughout the Ganga, Brahmaputra and Meghna river systems in India and Bangladesh, with very small numbers present in Nepal (Smith et al. 1994). Although the aggregate range-wide abundance of Ganges River Dolphins were estimated by Jones (1982) as 4000-5000 individuals and more recently by Mohan et al. (1997) as fewer than 2000, these were only guesses (Smith et al. 2004). Population assessments conducted within isolated portions of the huge network of riverine and deltaic dolphin habitats have been based on counts. Few rigorous estimates of absolute abundance, with estimates of precision, are available for the Ganges River Dolphin anywhere in its range (Smith et al. 2004). Sinha et al. (2000) documented 22 to 32 animals during May 1994 in the Koshi River in Indian territory from the Koshi Barrage to $60 \mathrm{~km}$ downstream. Subsequently, Sinha \& Sharma (2003) during March 2001 reported 87 animals downstream from Koshi Barrage to the confluence with the Ganga at Kursela in India. The studies conducted in the Nepal section of the Koshi River by Shrestha (1989) found a population of eight dolphins between the Koshi Barrage and Barahachetra. 
Smith et al. (1994), found only three dolphins between the Koshi Barrage and the confluence of the Arun and Sun Koshi rivers and two dolphins downstream of the Koshi Barrage during March-April, 1993. Chaudhary (2007) found no dolphins upstream of the Koshi Barrage in the river section between the barrage and Chatara, but reported a population of 10 to 15 dolphins within $2 \mathrm{~km}$ downstream of the barrage during October 2006 and January 2007. The survey data implies that the number of dolphins in the Koshi River is variable.

The Koshi River (Fig. 1) is a trans-boundary river that originates in Tibet (Autonomous Region of China) and flows through Nepal and then India. It is one of the largest tributaries of the Ganges. It has seven Himalayan tributaries: Sun Koshi, Tama Koshi, Dudh Koshi, Indrawati, Likhu, Arun and Tamur, and is popularly known as SaptaKoshi in Nepal and Koshi in India. The Koshi River is one of the extreme upstream limits of Ganges River Dolphin distribution. Koshi Tappu Wildlife Reserve (Fig. 2 ) is located $6 \mathrm{~km}$ upstream of the Koshi Barrage on the floodplain of this river. It was gazetted in 1976 to preserve habitat for the only remaining population of Wild Water Buffalo, Arna Bubalus arnee. The threatened Gharial crocodile and Gangetic Dolphin also occur in the reserve.
In Nepal, the river dolphin is protected by Section 10 of the National Parks and Wildlife Conservation Act 1973 and it is among 27 protected mammals in Schedule I (His Majesty Government of Nepal/HMGN 1973). In 1987, Koshi Tappu was declared a Ramsar site, a wetland of international significance. In 2004, the Government of Nepal declared a $173.5 \mathrm{~km}^{2}$ buffer zone surrounding the Reserve. The average annual flow of Koshi River at Chatara is about $1,600 \mathrm{~m}^{3} / \mathrm{s}$ and the peak flood generally occurs in June to July (average flood discharge $11,400 \mathrm{~m}^{3} / \mathrm{s}$ ) when the monsoon rain dominates the river flow regime. About $80 \%$ of the total annual rainfall occurs during the monsoon season. The extreme flow in the Koshi River at Chatara station was $25,879 \mathrm{~m}^{3} / \mathrm{s}$ in 1968 followed by $24,241 \mathrm{~m}^{3} / \mathrm{s}$ in 1954 and then about $24,000 \mathrm{~m}^{3} / \mathrm{s}$ in 1980 (UNESCO 2009). The breach of the Koshi embankment occurred during the summer flood in 2008. The mean flood discharge at Chatara during August 2008 was $5,120 \mathrm{~m}^{3} / \mathrm{sec}$ and peak flood on 18 August 2008 was only about $4,250 \mathrm{~m}^{3} / \mathrm{s}$ when the breach occurred (UNESCO 2009). The river not only shapes the physical features of the region, but also modifies the ecosystem of the area and has a profound impact on the socio-economic characteristics of the local communities'

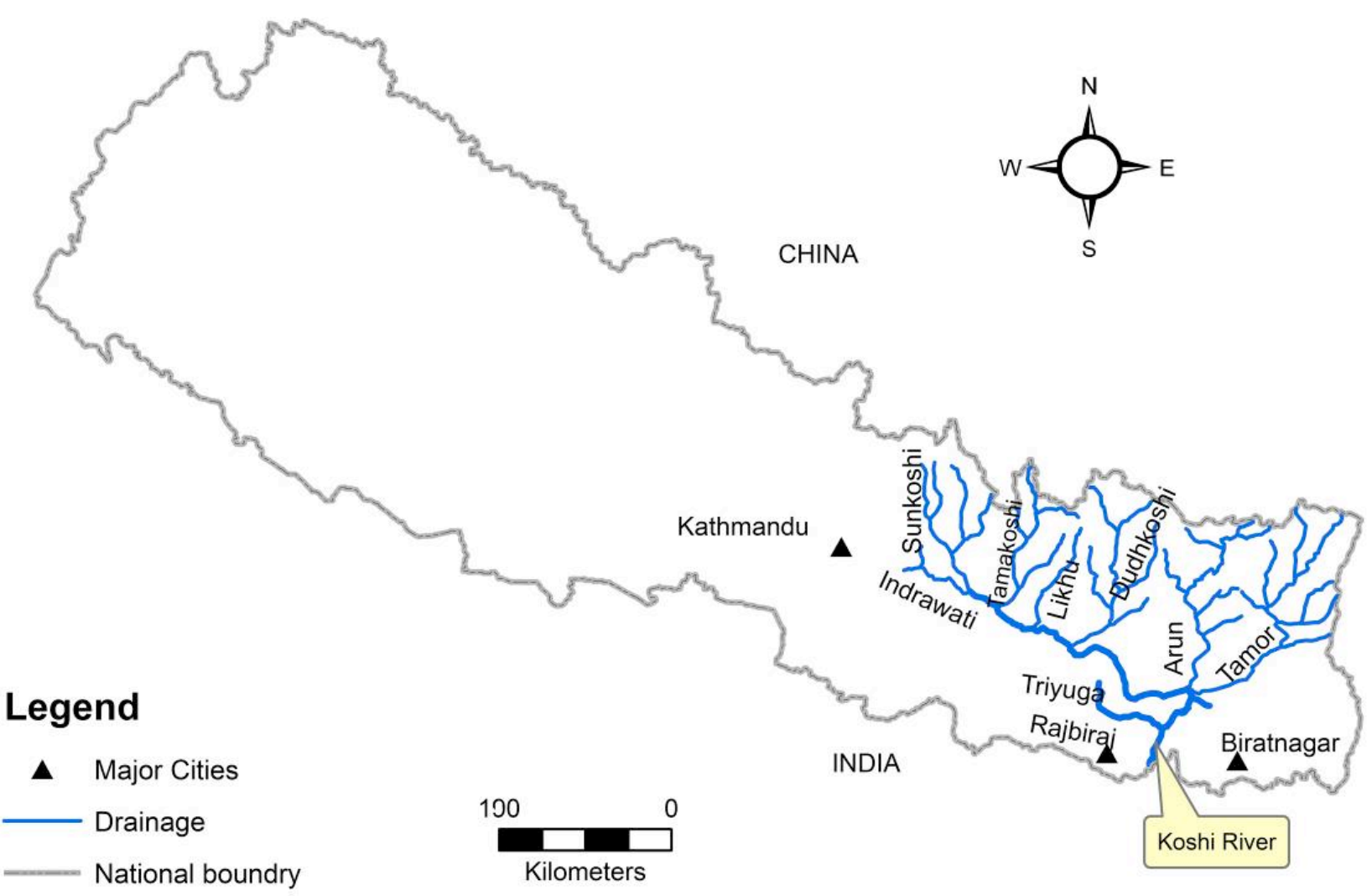

Figure 1. Koshi River basin, Nepal with its seven major tributaries, the Indrawati, the Sun Koshi, the Tama Koshi, the Likhu, the Dudh Koshi, the Arun and the Tamor. The Triyuga River drains the southern Mahabharat range and flows from the west into the Koshi. The altitude of the basin ranges from only $65 \mathrm{~m}$ near the Nepal-India boarder in the south to above $8000 \mathrm{~m}$ in the north within a short distance of about $150 \mathrm{~km}$. 


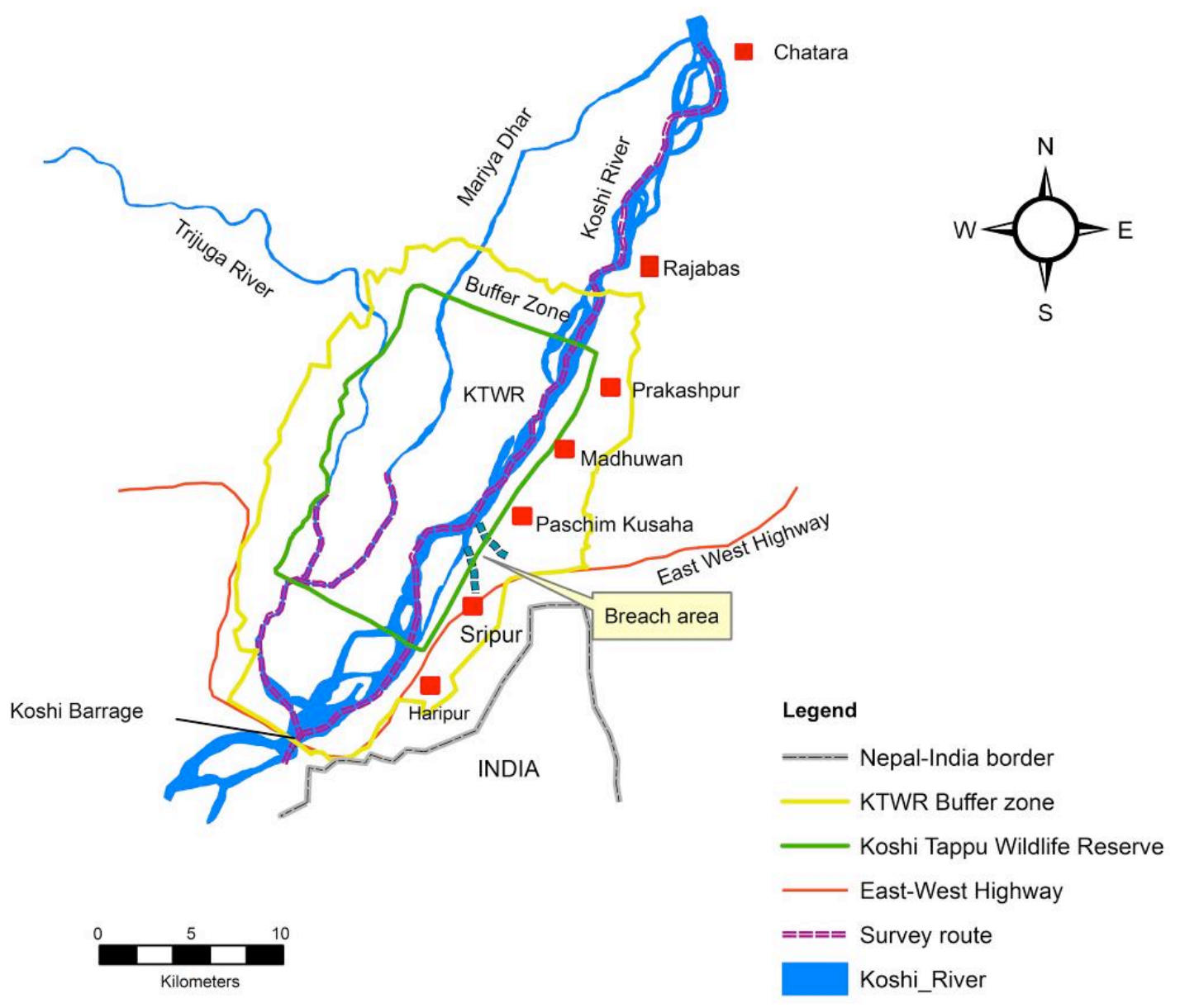

Figure 2. Map showing survey route, Koshi Tappu Wildlife Reserve and its buffer zone. The red symbol indicates the adjacent villages. The breach area is $12 \mathrm{~km}$ upstream from the Koshi Barrage.

resident in the buffer zone. The river is characterized by: (i) alluvial braided channels, (ii) relatively high velocity, (iii) large seasonal and annual variations in stream flow and sediment transport, and (iv) mixed use riparian areas, with small settlements of subsistence farmers and fishermen and forested jungle and grassland (Smith et al. 1994) contained within Koshi Tappu Wildlife Reserve.

Between 1958 and 1964, a barrage was constructed on the Koshi River in Nepal, about $15 \mathrm{~km}$ upstream of the international border with India with the eastern and western embankments bounding the river floodplain (UNESCO 2009). The construction of the barrage has changed the pattern of deposition and braiding of the river i.e., decreased braiding activity in downstream of the barrage and increasing sedimentation in the upstream of the barrage. The Koshi River, which was earlier shifting its course gradually, changed its course dramatically during the monsoon of 2008 when it made a $2 \mathrm{~km}$ breach in an embankment in Kusaha Village (Fig. 2) into a settlement area. This sudden shift in the course of Koshi River caused a dramatic change in the physical landscape and has caused subsequent effects on human

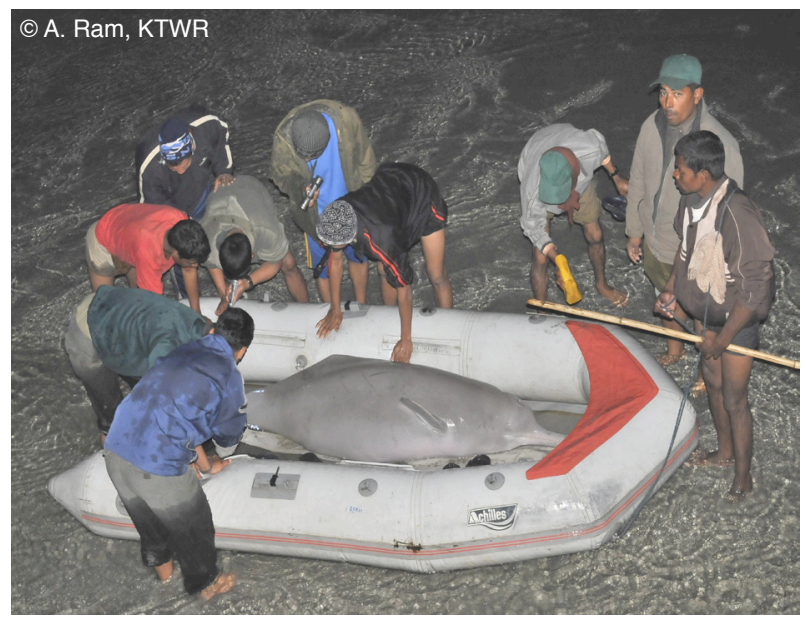

Image 1. Rescue of dolphin after Koshi flood in 2008.

settlements. During the flood, three marooned dolphins were found to be trapped in Sripur Village near the NepalIndia border; two of them were rescued and released later into the Koshi River near Paschim Kusaha Village (Image 


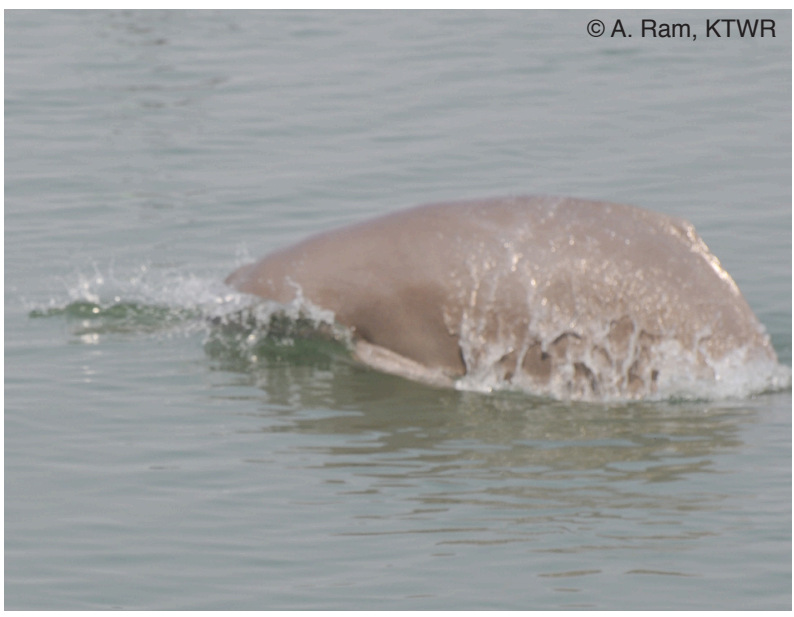

Image 2. Ganges River Dolphin Platanista gangetica gangetica in the Koshi River, Nepal.

1) by the Koshi Tappu Wildlife Reserve personal while the other died. The reconstruction of the embankment and diversion of the water flow into its old channel through the barrage was completed in January 2009. The Koshi River course was connected directly to the Ganga River for five months. Given the large changes in the Koshi River in 2008, a population survey of the Endangered Ganges River Dolphin (Image 2) was conducted to ascertain its current status.

\section{MATERIALS AND METHODS}

We conducted three surveys of the Ganges River Dolphin on 25-28 March 2009, 21-24 May 2009 and 1720 November 2009. This season was selected because the river discharge is at its minimum and dolphins remain concentrated in a narrower channel and are therefore easier to observe and count. Moreover, to avoid the seasonal migration of dolphins during the high water level, the survey was conducted in these seasons (preand post-monsoon), as it provides best conditions for population assessment.

The survey design principles followed those used in previous studies conducted by different authors (Shrestha 1989; Smith et al. 1994; Chaudhary 2007). Based on local consultations and information from the Reserve staff, all potential sites frequented by dolphins were sketched and mapped on a topographic sheet. A survey was then conducted in the entire river stretch from Chatara to $2 \mathrm{~km}$ downstream of Koshi barrage including the Triyuga and Mariya rivers (tributaries of the Koshi) to document the distribution of dolphins. Special attention was paid in the identified potential dolphin habitats in the Koshi River.

The survey was carried out by boat from Chatara to the Koshi Barrage including the Triyuga River and on foot along the river banks downstream of Koshi Barrage and along the Mariya River. The Koshi River was divided into six sections namely Chatara to Rajabas (A), Rajabas to Prakashpur (B), Prakashpur to Cofferdam (C), Cofferdam to Haripur (D), Haripur to Koshi Barrage (E) and south of Koshi Barrage (F). Surveys were conducted by two teams of researchers working in different areas, simultaneously. Oneteamsurveyed the KoshiBarrageareaincluding Mariya and Triyuga rivers while the other team made a survey from Chatara to Koshi Barrage. The teams remained in mobile phone contact to coordinate searching effort and avoid double counting the same animal. Each team was led by a researcher (Deep Narayan Shah and Nilamber Mishra) who had prior experience on dolphin surveys. The survey boat followed a single transect, following the deepest channel and moving from one bank to another. The speed of the boat was maintained at $5-7 \mathrm{~km} / \mathrm{h}$ in a downstream direction. Six observers recorded sighting of dolphins with four forward observers, two rear observers and a data recorder in each team. The areas of favourable dolphin microhabitats such as confluences, meandering, downstream of sandbars, Koshi Barrage areas etc. were given greater attention. We used a direct count method (Smith et. al. 1994; Sinha \& Sharma 2003) to estimate the population. When dolphins were sighted we remained in the area for approximately 30 minutes before recording a best estimate of the number of animals. Further standardized point counts were done at the confluence of Triyuga River and at the downstream of Koshi Barrage. The sighting locations were recorded by a Garmin GPS, and the time of the record was documented. Dolphin encounter rate was calculated by dividing the number of dolphins sighted by the total length of the surveyed river stretch measured by GPS.

The direct count of the fisherman was done each day in each section of the Koshi River from Chatara to downstream of Koshi Barrage during the dolphin survey. They were identified either with fish nets or other fishing activities using fishing boats. They were also recognized with the fishing license issued by Koshi Tappu Wildlife Reserve administration.

A key-informants interview survey among 50 people was conducted in the vicinity of the Koshi River to generate and substantiate information about the presence and abundance of dolphins in the area and about its population trend. It was conducted in an informal way with open-ended questions with the local people. Qualitative information on the occurrence and distribution of dolphins was obtained from the Koshi Tappu Wildlife Reserve naturalists, biologists, buffer zone committees and line agencies, using semi-structured interviews. Structured interviews were mainly employed for knowledgeable local fishermen who spend most of their time on the Koshi River.

In order to identify the current threats and challenges to the existing population, a focus group discussion was conducted with the user groups and user committees of 
the Reserve buffer zone. Information on recent sightings was reviewed and measures that could be taken to minimize the threats at the local level were discussed and documented.

\section{RESULTS}

An estimated total of 11 dolphins, five upstream and six just downstream to Koshi Barrage were recorded in the entire $49 \mathrm{~km}$ survey area with an encounter rate of 0.23 dolphins per $\mathrm{km}$ in the Koshi River system within the

Table 1. The distribution of dolphins in different segments of the Koshi River, Nepal

\begin{tabular}{|c|c|c|}
\hline Area & $\begin{array}{l}\text { Location } \\
\text { GPS Reading }\end{array}$ & $\begin{array}{l}\text { No. of dolphins } \\
\text { sighted/best } \\
\text { estimate }\end{array}$ \\
\hline Rajabas, Prakashpur & $\begin{array}{l}26^{\circ} 43^{\prime} 10.9^{\prime \prime} \mathrm{N} \\
87^{\circ} 05^{\prime} 48.4^{\prime \prime} \mathrm{E}\end{array}$ & 1 \\
\hline $\begin{array}{l}\text { Cofferdam (downstream to the } \\
\text { high electric transmission-third } \\
\text { tower) }\end{array}$ & $\begin{array}{l}26^{\circ} 41^{\prime} 41.1^{\prime \prime} \mathrm{N} \\
87^{\circ} 03^{\prime} 51.8^{\prime \prime} \mathrm{E}\end{array}$ & 1 \\
\hline $\begin{array}{l}\text { Kusaha Breach region } \\
\text { Haripur near vulture nest area }\end{array}$ & $\begin{array}{l}26^{0} 38^{\prime} 41.37^{\prime \prime} \mathrm{N} \\
87^{\circ} 011^{\prime} 01.02 " \mathrm{E} \\
26^{\circ} 39^{\prime} 59.288^{\prime \prime} \mathrm{N} \\
87^{\circ} 01^{\prime} 16.83 ” \mathrm{E}\end{array}$ & 1 \\
\hline $\begin{array}{l}\text { Triyuga dovan area } \\
\text { (just upstream to Koshi Barrage) }\end{array}$ & $\begin{array}{l}26^{0} 34^{\prime} 18.6^{\prime \prime} \mathrm{N} \\
86^{\circ} 57^{\prime} 7.5^{\prime \prime} \mathrm{E}\end{array}$ & 1 \\
\hline $\begin{array}{l}\text { downstream of Koshi barrage } \\
\text { (within } 2 \mathrm{~km} \text { stretch) }\end{array}$ & $\begin{array}{l}26^{0} 31^{\prime} 26.3^{\prime \prime} \mathrm{N} \\
86^{0} 55^{\prime} 49.8^{\prime \prime} \mathrm{E}\end{array}$ & 6 \\
\hline
\end{tabular}

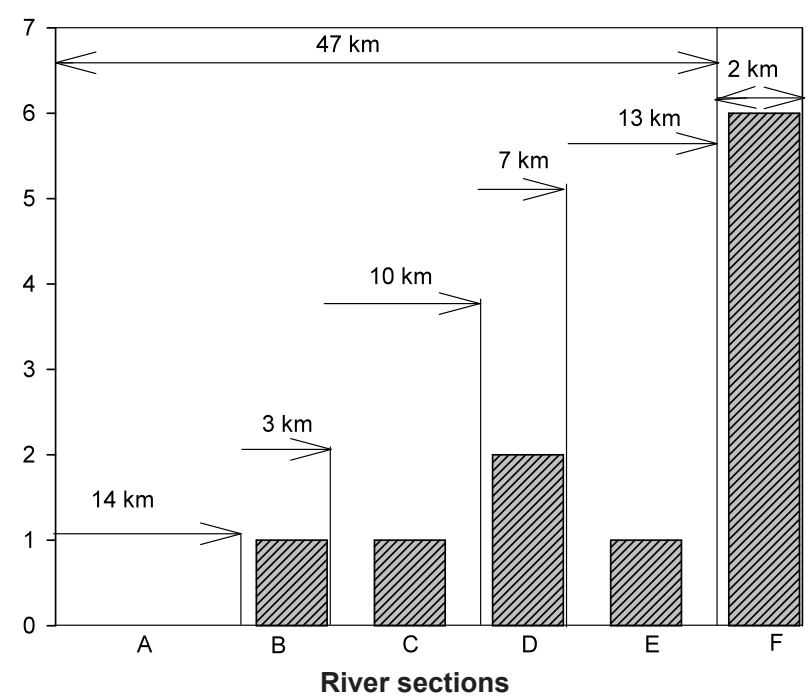

Figure 3. Distribution of dolphins along Koshi River from Chatara to $2 \mathrm{~km}$ downstream of Koshi Barrage. River sections: A - Chatara to Rajabas; B - Rajabas to Prakashpur; C - Prakashpur to Cofferdam; D - Cofferdam to Haripur; E - Haripur to Koshi Barrage; F - South of Koshi barrage upto $2 \mathrm{~km}$. (figure not to scale). territory of Nepal. The present study identified the Koshi Barrage area as the hotspot as the highest number of dolphins was sighted at this location despite a high level of human disturbance.

Dolphins were distributed (Table 1) in the upstream of Koshi Barrage i.e., in Prakashpur, Cofferdam, Haripur, the confluence of Triyuga River and downstream of Koshi Barrage (Fig. 3). Downstream of the barrage dolphins were seen to be concentrated just close to the Koshi Barrage in the Nepalese territory. Dolphins were mostly observed solitarily or in small groups but as many as two to six individuals occurred in the main channel of the Koshi River. They were mostly seen to use the counter current pools just below the river convergences (Triyuga and Koshi), below mid Channel Islands (Haripur area), sharp meanders (Rajabas, Prakashpur) and downstream of Koshi Barrage. No dolphins were recorded in the Mariya and Triyuga rivers. Locals reported sightings of dolphin activity in Chatara area in the past but animals have not been sighted there since the construction of the Chatara irrigation canal in 1975.

We recorded in average a total of 215 fishermen per day in the Koshi River during the survey, of which $50 \%$ were concentrated in the barrage area. We encountered a minimum (2.15 fishermen $/ \mathrm{km}$ ) in the stretch from Rajabas to Haripur and the greatest number (10.7 fishermen/km) in the stretch from Haripur to $2 \mathrm{~km}$ downstream of Koshi Barrage.

\section{DISCUSSION}

Our survey indicates that the Koshi Barrage area is the most important stretch of the Koshi River in terms of dolphin abundance. We encountered the dolphins at the rate of 0.23 dolphins per $\mathrm{km}$. The present encounter rate in Koshi River is similar to the findings in Brahmaputra River (Wakid 2009) and is comparatively lower than other major habitats of the Gangetic Dolphin. In the KarnaphuliSangu river complex and the lower Sangu of Bangladesh, the encounter rate was 0.76 and 1.36 dolphins per km respectively (Smith et al. 2001). In the Vikramshila Gangetic Dolphin Sanctuary, located in the middle reaches of Ganges mainstream, the encounter rate was 0.81 dolphins per $\mathrm{km}$ (Sinha et al. 2000). However, this survey was conducted at the upstream limit of the dolphin distribution and a lower encounter rate than in the center of the distributional range is to be expected.

The survey results of dolphin population from 1989 to 2007 in the Koshi River within the territory of Nepal are variable and are also incomparable due to different methods and different geographic coverage, however, we recorded the highest number of dolphins i.e., 11 till date (Table 1). The larger count of dolphins upstream of Koshi barrage recorded in the current study may be attributed to the systematic survey and its wider geographic coverage 
than previous surveys. It may also be due to movement of dolphins into the area from downstream when there was a direct connection for five months between the main course of the Koshi River and the Ganges during the breach of the eastern embankment in Paschim Kusaha Village (12km upstream of Koshi Barrage) in the year 2008. Also the higher count could be due to natural growth of this population.

The Reserve authority issued 144 fishing licenses to buffer zone fishermen in 2009 to promote controlled fishing within the reserve boundary. We observed that fishing was intensive in the river segment lying outside the Reserve as well as within the buffer zone (jurisdiction of KTWR). The intensive fishing during low water levels may have an adverse effect on dolphin prey availability.

The current result shows an encouraging population of dolphins in the Koshi River but the threats for conservation still remain challenging. Close monitoring of dolphins and their habitats involving local communities are required for long term conservation of the species in the Koshi River. The Government of Nepal, Ministry of Forest and Soil Conservation has implemented the project entitled "Conservation and Sustainable Use of Wetlands in Nepal" since 2008 for the conservation of wetlands and its key species. The project has targeted wetland dependent communities for their livelihood improvement and reducing their dependency on the wetlands. The project is also facilitating Koshi Tappu Wildlife Reserve to issue fishing licenses, to strictly monitor the mesh size of fishing nets and regulate fishing hours. A well structured community awareness programme, periodic monitoring, habitat management and livelihood interventions for the wetland dependent community is in place. Despite these undertakings, the long term conservation of the river dolphins is still a daunting task due to the numerous pressures on its habitat. The present political void of the country has had a profound impact in the law enforcement regime and it will take a while to bring the situation as before. Additionally, the barrage (a low gated dam of a length of $1150 \mathrm{~m}$ ) has isolated the dolphin population upstream from any possible genetic interchange with animals inhabiting downstream waters (Smith et al. 1994). Dolphins upstream of the barrage may occasionally move downstream through the barrage during flood periods, resulting in a permanent loss of animals to an already small and fragmented population, however it is also possible that animals may move upstream during floods. Some migratory human settlements use poison for fishing in the Koshi River which poses a direct threat to the dolphins. Plants such as Agave americana, Sapium insinge, Dioscorea sp., Euphorbia sp. are frequently used for fishing in the Koshi River (Yadav 2002; Chaudhary 2007).

\section{CONCLUSION}

Based on the findings of our study, it is concluded that the status and distribution of the Gangetic Dolphin in Koshi River within the territory of Nepal is satisfactory. We consider the dolphins inhabiting the Koshi River to be of special conservation value because of Koshi Tappu Wildlife Reserve that makes them a valuable economic resource for local eco-tourism development. The Ganges and Indus dolphins have been declining in range and small populations located upstream have been the first to disappear, therefore the continued survival of dolphins in the Koshi River in Nepal is encouraging. This may be the largest population of river dolphins remaining in Nepal and is therefore of national significance. However, the area is heavily affected by human activities mainly from over-fishing with a variety of traps, nets and poisons that degrade the habitat of the dolphin. Integral to sustainable conservation plans must be a high priority placed on the economic and social development of subsistence wetland dependent communities particularly fishermen living within the Koshi River basin. The protection of the river downstream of Koshi Barrage needs to be bolstered through an intense surveillance mechanism in order to keep vigil on the dolphins as well as to deter any illegal activity taking place within the vicinity.

\section{REFERENCES}

Chaudhary, S. (2007). Status of, and Threats to, the Ganges River Dolphin (Platanista gangetica) in the Koshi River, Nepal. MSc Thesis. Department of Economics, University of Klagenfurt, Austria, $x+38 p p$.

HMGN (1973). National Parks and Wildlife Conservation Act, 1973. His Majesty's Government of Nepal. Department of National Parks and Wildlife Conservation, Kathmandu, Nepal.

Jones, S. (1982). The present status of the gangetic susu, Platanista gangetica (Roxburgh), with comments on the Indus susu P. minor Owen. FAO Advisory Committee on Marine Resources Research Working Party on Marine Mammals. FAO Fish Series 5(4): 97-115.

Kreb, D. \& Budiono (2005). Conservation management of small core areas: key to survival of a critical endangered population of Irrawaddy river dolphins Orcaella brevirostris in Indonesia. Oryx 39(2): 1-11.

Mohan, R.S.L., S.C. Dey, S.P. Bairagi \& S. Roy (1997). On a survey of Ganges River Dolphin Platanista gangetica of Brahmaputra River, Assam. Journal of the Bombay Natural History Society 94: 483-495.

Shrestha, T.K. (1989). Biology, status and conservation of the Ganges river dolphin, Platanista gangetica, in Nepal, pp. 70-76. In: Perrin, W.F., R.L. Brownell, Jr., Z. Kaiya \& L. Jiankang (eds.). Biology and Conservation of The River Dolphins. Occasional papers of the IUCN Species Survival Commission No. 3, IUCN, Gland, Switzerland.

Sinha, R.K. \& G. Sharma (2003). Current status of the Ganges river dolphin in the rivers Koshi and Son. Journal of the Bombay Natural History Society 100(1): 27-37.

Sinha, R.K., B.D.Smith, G. Sharma, K. Prasad, B.C. Chaudhary, K. Sapkota, R.K. Sharma \& S.K. Behera (2000). Status and distribution of the Ganges Susu, Platanista gangetica, in the 
Ganges River system of India and Nepal. pp. 54-61. In: Reeves, R.R., B.D. Smith \& T. Kasuya (eds). Biology and Conservation of Freshwater Cetaceans in Asia. IUCN Species Survival Commission Occasional Paper No. 23, IUCN, Gland, Switzerland and Cambridge, UK.

Smith, B.D., R.K. Sinha, U. Regmi \& K. Sapkota (1994). Status of Ganges River Dolphins (Platanista gangetica) in the Karnali, Mahakali, Narayani and Koshi rivers of Nepal and India in 1993. Marine Mammal Science 10(3): 368-375.

Smith, B.D., A. Benazir, A.M. Edrise \& G. Braulik (2001). Status of the Ganges River Dolphin or Shushuk Platanista gangetica in Kaptai Lake and the southern rivers of Bangladesh. Oryx 35: 61-72.

Smith, B.D., G. Braulik \& R.K. Sinha (2004). Platanista gangetica ssp. gangetica. In: IUCN 2010. IUCN Red List of Threatened Species. Version 2010.2. <www. iucnredlist.org>. Downloaded on 18 August 2010.

UNESCO on behalf of OCHA and UNCT, Nepal (2009). Report of the Rapid Hazard and Risk Assessment Post-Flood Return Analysis. Nepal, v+104pp.

Wakid, A. (2009). Status and distribution of the endangered Gangetic Dolphin (Platanista gangetica gangetica) in the Brahmaputra River within India in 2005. Current Science 97(8): 1143-1151.

Yadav, S. (2002). Survey of Capture fisheries in the Koshi River Basin. pp. 317-326. In: Peter, T. \& S.B. Swar (eds.). Cold Water Fisheries in the Trans-Himalayan Countries. FAO of United Nations Technical paper No. 431, Rome, Italy. <http://www.fao.org/ docrep/005/y3994e/y3994e0r.htm>. On-line version dated 21 September 2010.
Author Details: TOP BAHADUR KHATR's research interests are in resource management, parkpeople interface, community stewardship and wetland conservation in Asia. $\mathrm{He}$ has been implementing various integrated conservation and development projects in and around the protected areas of Nepal for over two decades. In addition, he is associated with a number of professional and scientific organizations.

DeEP Narayan Shah's research interests are in aquatic biology, ecology and wetland conservation in Asia. He has been conducting research in different wetlands of Nepal and is associated with several national and international scientific organizations.

NILAMBER MISHRA's research interests are in the ecology and conservation of the large mammals of South Asia. He is currently the Conservation Officer (Warden) of Koshi Tappu Wildlife Reserve. 